\title{
Touchwood Hills
}

\author{
By R. C. MacKenzie
}

Director S.N H.S.

Where popular woods, and meadows lie, And blue swamp waters mirror sky.

These hills, all varied shades of green, Are just as they have always been.

Arthur's farm lies in the rolling Touchwood Hill country. It was his homestead, and he has lived there most of his life. In his first days in the country he had been a stage driver. Over the old winding, rutted way that was once called Touchwood Trail, he had driven passengers and mail. Qu'Appelle to Fort Qu'Appelle and from the Fort to Cutawa, stopping house, stage post, and telegraph office, on the first telegraph line in the Saskatchewan country. A nane almost forgotten now except by a few ol dtimers. Many are the tales he can tell. Shades of rebeilion and indian warfare, horsethieves, and hold-up men.

I was being shown some perfectly sound poplar logs taken from an old barn built over fifty years ago, and recently torn down to make room for a more modern structure. White poplar has been considered a poor building material as logs or lumber, but these logs had stood the test of time remarkably well.

Was not the White Poplar bigger and more plentiful in those early days? I asked. Arthur says no. Much land that was prairie then is covered with poplar bluffs now. There were big trees then, but the need for building logs soon almost eliminated the supply. Today, logs for building are not often sought after, and with the increase of oil-burning equipment in farm houses less trees are being felled for fuel. Now in coulees and on hillside beyond the reach of cultivation, trees are growing as tall as any seen by the first settlers.

The grasslands are making a comeback too. The last several years of abundant moisture have helped much.

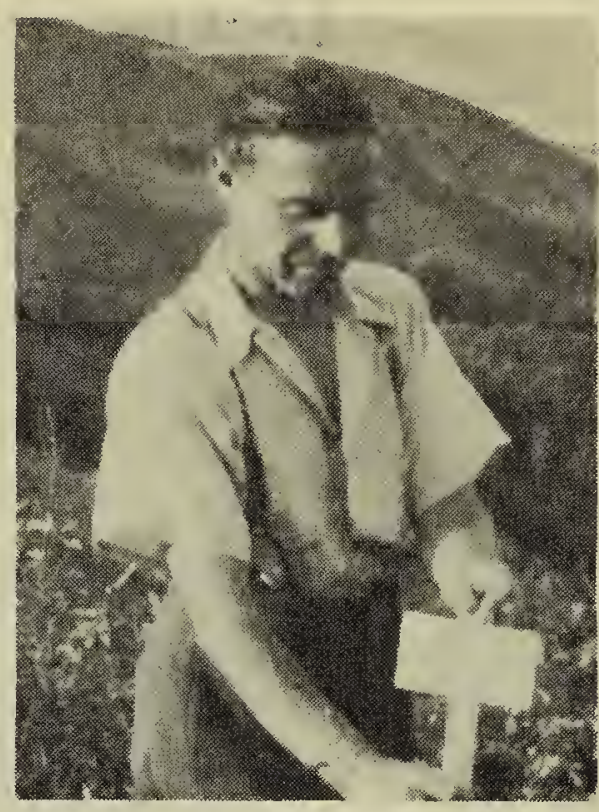

The decrease of cattle on farms, resulting in less grazing, has given grasses and plants a chance to grow. Red patchs of Tiger Lilies are common again. Seneca Root, an almost forgotten plant in most districts, can again be found near the edges of bluffs and woods.. Indian Onion, Gailardia, Bluebell, Summer Aster, and coneflower are all on the increase.

I was interested in trees. Birch, Black Poplar, the many varieties of willows, but most of all in White Poplar, Populus Tremuloides, the Aspen of our bluffs and parkl ands.

The next day we roamed across several heavily wooded sections to find hidden groves of birch on the north slopes of hills, Black, or Balsam Poplar along the edges of sloughs, and White Poplar and willow abundant everywhere. I saw some of these trees that were fifty feet high and more than twelve inches in diameter which though not the tallest of their kind, are considered big trees in this part of the country.

Good seasons for growing, and the fact that more trees are being left to reach inaturity, are factors that are helping bluff and woodland to recreate a new wilderness.

A week later I happened to be travelling along highway number 20 through the country east of LongL ake. East of the road the billowing hills of the Last Mountain country rose up ridge beyond ridge. The green wheatlands had infringed upon the lower slopes, but higher up were uncultivated grassy upland meadows dotted with bluffs, and beyond, covering the highest ridges, miles of dark green poplar

(continued to page 18) 
spur short, less than $2 \mathrm{~mm}$. long. Occasional along cool forest streams and swamps. June -- July.

5. Viola pedatifida G. Don. PURPLE PRAIRIE VIOLET. Plant stemless, minutely,pubescent to glabrate, from an erect rhizome; lvs. divided to the base into many segments; firs. large, 12 to $15 \mathrm{~mm}$. across, reddish-violet, usually overtopping the leaves, the 3 lower petals veined with darker violet and densely. bearded at the base; sepals ciliate. Dry gravelly hills; plains. May.

6. Viola Rafinesquii Greene. FIELD PANSY. Slender leafy stemmed annual, simple or branch, 3 to 6 in. high; lvs, small, basal ones rounded, the cauline spatulate to obovate, slightly undulate; stipules leaf-like, deeply cut; flrs. bluish-white to cream, 7 to $10 \mathrm{~mm}$. long, or twice as long as the sepals. (V. Kitaibeliana R. \& S. var Rafinesquit (Greene) Fernald). In grain fields, introduced from Eurasia. May -. July.

7. Viola renifolia A. Gray. KIDNEY-LEAVED VIOLET. Plant stemless, gl abrous or pubescent; rhizome, non-stoloniferous; lvs.

to orbicular with open sinus, coarsely crenate, 1.5 to $5 \mathrm{~cm}$. broad, lustrous beneath; flrs. white, on peduncles 3 to 3 in. long, petals beardless, the 3 lower veined with purple. ( $V$. Brainerdii Greene). Frequent in cool, rich moist woods May -- June.

8. Viola rugulosa Greene. TALL STEMMED WHITE VIOLET. Stems 8 to 24 in. high, single or few from a slender rhizome, spreading rapidly by elongating, forking subterranean stoluns; lvs. broadly cordate-ovate, short acute, slightly wrinkled, dentate, pubescent beneath, sinus deep, basal lvs. on long petioles, the blades sometimes 4 in. broad when fully developed; flrs. from axils of the upper leaves, petals 10 to $12 \mathrm{~mm}$. long, white, yellow at the base, the 3 lower veined with dark violet, all suffused with reddish-violet on the vack. ( $V$. Rydbergii Greene). Woods especially abundant in the aspen grove section. May -- July.

Touchwood Hills --

(con tinued from page 3)

woods. By way of a winding earth road I made a side trip into the hills. Leaving my car on a hillcrest, I entered the cool green depths of the woods. Through underbush of Saskatoon-bush, past the fruiting season but still bearing some sweet purple berries, through tangled thickets of chokecherry, dogwood, willow, and pincherry, up steep banks where wild raspberry still held delicious juicy fruit, I followed a narrow winding deer trail that led ine to a sinall slough where ducks rose in scattering flight from the water, and redwing bl ackbirds perched on swaying rushes.

Beyond the slough, the trail led out into the sunlight again. Across grassy meadows gay with flowers, Yarrow, Bluebell, Coneflower, and Bergamot. A country unspoiled, almost untouched by the hand of man; this is how it must have looked a $h$ undred years ago.

Wide stretches of wheatland now cover the once grassy vastness of the Buffalo Plains, but here high in the hills the scene is little changed. It needs only a cree hunter with bow, arrow, and knife stalking along the winding trail through the cool and shady places, or on the windswept uplnad meadows, a deerskin clad figure, inounted on a light footedhalfwild pony.

Isaac Cowie from Fort QuAppelle, scouted this country for the Hudsons Bay Company in 1871 , seeking a good site for the then new trading post of Last Mount ain House, later located near the south end of the lake. More than once these wooded hills were the gathering place of Metis buffalo hunters. Brigades of over a hundred carts have gathered here. Indian woman preparing food over many fires; lighting the night like grounded stars. Cree words mixed with french in merry chansons. Wild revels, solemn councils, at unrecorded meetings long ago.

'These are shadows from the past, but in the wild and unspoilt places nature rhanges little, flower and tree, sky and hill remain the same. 